\title{
Se-Jin Lee, myostatin discoverer, elected to the National Academy of Science
}

\author{
David J Glass ${ }^{1 *}$ and Bruce M Spiegelman²
}

\begin{abstract}
Se-Jin Lee was elected member to the National Academy of Sciences on 28 April 2012. Dr Lee is responsible for the discovery of myostatin, a critical regulator of skeletal muscle mass and function. He also determined the primary binding receptor for myostatin, and has characterized additional transforming growth factor- $\beta$ family members acting in this pathway.
\end{abstract}

Keywords: National Academy of Sciences, Skeletal muscle development, Myostatin

\section{Commentary}

Professor Se-Jin Lee was elected on 28 April to the United States National Academy of Sciences for his research achievements, most notably the discovery of myostatin and its role in skeletal muscle maintenance.

Dr Lee is a Professor of Molecular Biology and Genetics at Johns Hopkins University. He holds an MD and $\mathrm{PhD}$, and he joined Hopkins after a period as an associate at the Carnegie Institution for Science.

His first major paper in the area that led him on his most fruitful research path was published in Nature in 1994 [1]. In that study, Professor Lee reported on the discovery of several transforming growth facto (TGF) $-\beta$ family members: growth differentiation factor (GDF) 5,6 and 7. Next, in 1997, Professor Lee and his co-authors Alexandra McPherron and Ann Lawler described the identification of myostatin, also known as GDF8, via RTPCR, using degenerate primers from TGF- $\beta$ family member homology domains [2]. In that same manuscript, they described the myostatin mouse knockout, and the dramatic skeletal muscle hypertrophy caused by deletion of myostatin, a phenotype that still manages to startle. A two- to three-fold increase in muscle mass was observed in the GDF8 null muscle [2]. Later that year, McPherron and Lee also reported that Piedmontese and Belgian Blue cattle, notable for their hypermuscularity,

\footnotetext{
* Correspondence: david.glass@novartis.com

${ }^{1}$ Novartis Institutes for Biomedical Research, 100 Technology Square, RM4210, Cambridge, MA 02139, USA

Full list of author information is available at the end of the article
}

have naturally occurring disruptions of the myostatin locus [3].

Dr Lee went on to extensively study myostatin, and in subsequent papers demonstrated the loss of white fat that occurs upon induction of hypermuscularity by myostatin inhibition [4], and that administration of myostatin was sufficient to cause a phenotype reminiscent of cachexia [5]. He next showed that myostatin was regulated by a metalloprotease that activates it from a latent state [6], and identified the activin receptor type IIb receptor as one of the key receptors for myostatin [7]. This last paper highlighted an ongoing trend of first-author manuscripts for Dr Lee, a testament to his continued commitment to working at the bench.

Finally, Dr Lee has shown that other molecules in the TGF- $\beta$ pathway, notably the activins and follistatin, also regulate muscle mass $[8,9]$.

Dr Lee's contributions include the demonstration of potential therapeutic benefits for myostatin inhibition. The precise clinical setting in which myostatin blockade might be beneficial has not yet been finally determined in humans, but it is at least clear that human null mutations for myostatin have a similar phenotype of hypermuscularity [10]. One potential area for blockade of this family of factors is cancer cachexia, as was demonstrated with an activin receptor IIb trap [11].

Dr Lee's election to the Academy represents great recognition both for him and for the skeletal muscle field as a whole. His career is a testament to continued close study of a mechanism, leading to the initiation of an entirely new field of basic and biomedical research. 


\section{Author details}

'Novartis Institutes for Biomedical Research, 100 Technology Square, RM4210, Cambridge, MA 02139, USA. ${ }^{2}$ Dana-Farber Cancer Institute and Department of Cell Biology, Harvard Medical School, Boston, MA 02115, USA.

Received: 8 May 2012 Accepted: 7 June 2012

Published: 7 June 2012

\section{References}

1. Storm EE, Huynh TV, Copeland NG, Jenkins NA, Kingsley DM, Lee S-J: Limb alterations in brachypodism mice due to mutations in a new member of the TGF[beta]-superfamily. Nature 1994, 368(6472):639-643.

2. MCPherron AC, Lawler AM, Lee SJ: Regulation of skeletal muscle mass in mice by a new TGF-beta superfamily member. Nature 1997, 387(6628):83-90.

3. McPherron $A C$, Lee $\mathrm{SJ}$ : Double muscling in cattle due to mutations in the myostatin gene. Proc Natl Acad Sci U S A 1997, 94(23):12457-12461.

4. McPherron AC, Lee SJ: Suppression of body fat accumulation in myostatin-deficient mice. J Clin Invest 2002, 109(5):595-601.

5. Zimmers TA, Davies MV, Koniaris LG, Haynes P, Esquela AF, Tomkinson KN, McPherron AC, Wolfman NM, Lee SJ: Induction of cachexia in mice by systemically administered myostatin. Science 2002, 296(5572):1486-1488

6. Wolfman NM, McPherrin A, Pappano W, Davies M, Song K, Tonkinson K, Wright J, Zhao L, Sebald S, Grenspan D, et al: Activation of latent myostatin by the BMP-1/tolloid family of metalloproteinases. Proc Natl Acad Sci U S A 2003, 100(26):15842-15846,

7. Lee S-J, Reed LA, Davies MV, Girgenrath S, Goad MEP, Tomkinson KN, Wright JF, Barker C, Ehrmantraut G, Holmstrom J, et al: Regulation of muscle growth by multiple ligands signaling through activin type II receptors. Proc Natl Acad Sci USA 2005, 102(50):18117-18122.

8. Lee SJ, McPherron AC: Regulation of myostatin activity and muscle growth. Proc Natl Acad Sci USA 2001, 98(16):9306-9311.

9. Lee S-J: Quadrupling muscle mass in mice by targeting TGFbeta signaling pathways. PLoS One 2007, 2(8):e789.

10. Schuelke M, Wagner KR, Stolz LE, Hubner C, Riebel T, Komen W, Braun T, Lee S-J: Myostatin mutation associated with gross muscle hypertrophy in a child. N Engl J Med 2004, 350(26):2682-2688

11. Zhou X, Wang LJ, Lu J, Song Y, Kwak KS, Jiao Q, Rosenfeld R, Chen Q, Boone T, Simonett WS, et al: Reversal of cancer cachexia and muscle wasting by ActRIIB antagonism leads to prolonged survival. Cell 2010, 142:531-543.

doi:10.1186/2044-5040-2-11

Cite this article as: Glass and Spiegelman: Se-Jin Lee, myostatin discoverer, elected to the National Academy of Science. Skeletal Muscle 2012 2:11.

\section{Submit your manuscript to a SpringerOpen ${ }^{\circ}$ journal and benefit from:}

- Convenient online submission

- Rigorous peer review

- Immediate publication on acceptance

- Open access: articles freely available online

- High visibility within the field

- Retaining the copyright to your article 